\title{
Plectranthus amiculatus and P. altanmouiensis (Lamiaceae): new species from Cape York Peninsula, Queensland, Australia.
}

\author{
Trevor C. Wilson ${ }^{1,2}$, Paul I. Forster ${ }^{3}$ and Matt A.M. Renner ${ }^{1}$ \\ ${ }^{1}$ National Herbarium of New South Wales, Royal Botanic Gardens \& Domain Trust, \\ Mrs Macquaries Road, Sydney NSW 2000, Australia \\ ${ }^{2}$ School of Life and Environmental Sciences, University of Sydney, NSW 2006, Australia \\ ${ }^{3}$ Queensland Herbarium, Department of Environment \& Science, Brisbane Botanic Gardens, \\ Mt Coot-tha Road, Toowong, Qld 4066, Australia. \\ ${ }^{2}$ Author for correspondence: trevor.c.wilson@rbgsyd.nsw.gov.au
}

\begin{abstract}
Two new species of Plectranthus L'Hér. are described from Cape York Peninsula, Queensland. Plectranthus amiculatus T.C. Wilson, P.I.Forst. \& M.A.M. Renner and P. altanmouiensis T.C. Wilson, P.I.Forst. \& M.A.M. Renner have restricted distributions on the peninsular tip and Altanmoui range, respectively. Both species are illustrated and notes on habitat, distribution, affinities and conservation status are provided.
\end{abstract}

\section{Introduction}

The Cape York Peninsula bioregion (CYP) is approximately $750 \mathrm{~km}$ long and 220,000 $\mathrm{km}^{2}$. It is the most northern section of Queensland and harbours a diverse flora. The exposed geology of CYP is of particularly early origin, having formed before or during the Mesozoic. The Hodgkinson Basin forms the eastern edge of Cape Melville and extends south towards Cooktown; it consists of a complex mosaic of geologies, wherein the Altanmoui range of Cape Melville consists of Permian granites overlaid with Cretaceous sedimentary rock (Biggs and Philip 1995). The northern tip of CYP also consists of granites and volcanics (Carboniferous in age) that extend across the Torres Strait -albeit mostly submerged- to the southern margin of Papua New Guinea (Willmott et al. 1973; Von Gnielinsky et al. 1997). In Cape Melville and the eastern ranges further north in CYP, the relief and steep slopes resulting from this geology provide a wealth of habitat for outcrop-loving plants such as Plectranthus L'Hér.

Plectranthus is a genus of fleshy to succulent herbs or shrubs found throughout the tropics (except in the Americas), and to a lesser extent, temperate regions such as southeastern Australia and southern Africa (van Jaarsveld 2006). In tropical latitudes, it is typically found in skeletal soils in rocky outcrop habitat and its fleshy to succulent habit permits its tolerance to long dry periods relieved by the annual monsoon. Although the diversity of Plectranthus is known to be particularly high in Southern Africa, a steady taxonomic endeavour for the past several decades has recognised many species (currently 48) in Australia, particularly in the north east of Queensland (Forster 1991, 1992, 1994, 1996, 1997, 1998, 2008, 2011, 2014, 2015). 
The numerous isolated ranges of CYP appear to have provided suitable conditions for a high diversity of Plectranthus, including ten endemic species. Four of these CYP endemics (P. dumicola P.I.Forst., P. megadontus P.I.Forst., P. batianoffii P.I.Forst., and P. ventosus P.I.Forst.) are found in the Cape Melville region, and another five (P. arenicola P.I.Forst., P. laetus P.I.Forst., P. pulchellus P.I.Forst., P. excelsus P.I.Forst., and P. venustus P.I.Forst.) are found in the region within or nearby Kutini-Payamu National Park (NP), which is approximately $200 \mathrm{~km}$ south of the peninsular tip. Plectranthus scutellarioides (L.) R.Br. and P. apreptus S.T.Blake - both of which are distributed throughout most of the Queensland wet tropics - are the only two Australian species recorded further north towards the Torres Strait islands (Atlas of Living Australia Atlas of Living Australia 2018). Yet the presence of P. apreptus on CYP is based on a single leafless specimen collected from Goods (Palilug) Island (Powell $8 \mathrm{MEL}$ ), which is $500 \mathrm{~km}$ north of other known collections. Although this specimen resembles P. apreptus superficially, it does not fit the description of P. apreptus since it has dark orange glands (as opposed to yellow), more flowers per verticillaster and longer spreading non-glandular trichomes on its calyces.

Exploration of CYP in 2015 aimed to collect specimens of Plectranthus for a comprehensive phylogenetic investigation on Australian Plectranthus. An unidentified species, very similar to P. batianoffii and P. diversus S.T.Blake, was collected in the southern portion of the Altanmoui range. Although the names P. batianoffii and $P$. diversus were applied to some specimens collected in the area, critical examination supports that these specimens and the unidentified specimen are an undescribed species. Another unidentified Plectranthus was found near Cape York, north of the Lockerbie scrub, and bears resemblance to the material collected from Goods (Palilug) Island. In this paper we describe both unidentified collections as a new species and provide them with a description, illustrations, images, and a table describing morphological differences. We follow the format of measurements and terminology used in preceding studies of Plectranthus (e.g. Forster 2015), include reproductive terminology and quantify indumentum following the format of other Lamiaceae studies (Conn 1992; Wilson and Conn 2015), and introduce a new method for measuring diagnostic bends in the corolla tube (Fig. 1). Measurements were made from living (P. amiculatus only), spirit and herbarium material; sessile glands and glandular trichomes were only measured from herbarium material since they become obscured or destroyed when preserved in spirit.

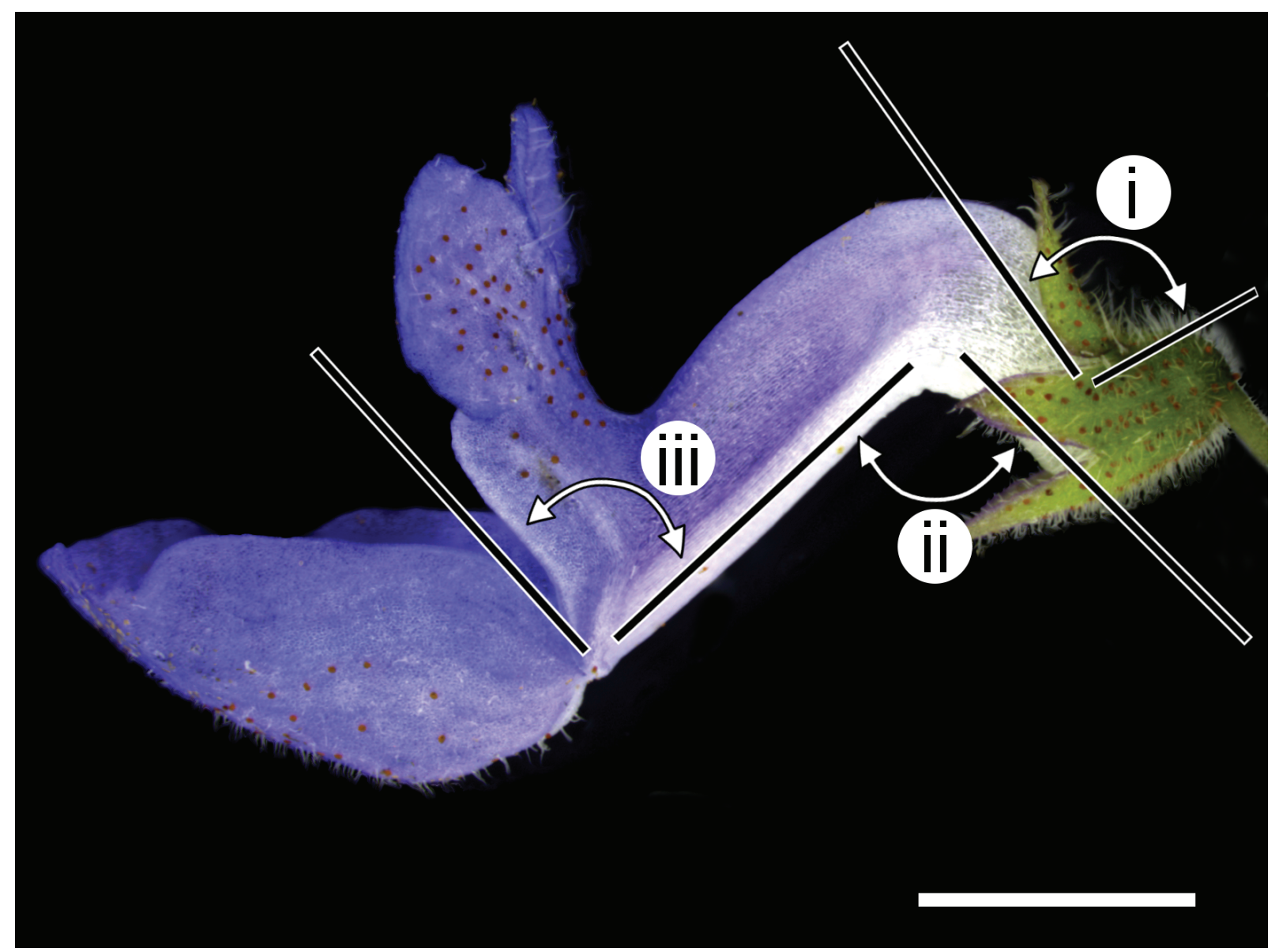

Fig. 1. Flower profile of P. amiculatus showing i) angle measurement of upward bend ii) angle measurement of downward bend and iii) angle measurement of lateral lobes respective of floral tube axis. Scale bar $=2.5 \mathrm{~mm}$. Photograph: T.C. Wilson. 


\section{Taxonomy}

\section{Plectranthus amiculatus T.C.Wilson, P.I.Forst. \& M.A.M.Renner, sp. nov.}

Diagnosis: Plectranthus amiculatus T.C.Wilson, P.I.Forst. \& M.A.M.Renner shares with P. apreptus the ovate leaf superficially appearing glabrous, leaf veins impressed adaxially and only slightly raised on the abaxial surface, lower calyx lobes not adjacent to corolla tube, and a similar corolla shape with a sharp $\left(90-115^{\circ}\right)$ downward bend in the corolla tube; but differs from P. apreptus by the longer and spreading non-glandular trichomes on leaves and stems (as opposed to shorter and antrorse), orange-coloured sessile glands densely covering stem below inflorescence (as opposed to yellow or yellowish orange), (6)12-14(16) flowers in a verticillaster (as opposed to 6-10(16), spreading hairs that are longer $(0.1-0.5 \mathrm{~mm}$ ) on the flowering calyx (as opposed to antrorse and $<0.2 \mathrm{~mm}$ ) and a pleasant scent when crushed (as opposed to scentless).

Type: Along Pajinka Road, Cook District, Queensland, $10^{\circ} 42.187^{\prime}$ S, 142 31.850' E, 8 Aug 2015, T.C. Wilson 595 \& M.A.M. Renner (holo: NSW985146; iso: BRI).

Erect to semi-erect, succulent perennial herb $20-40 \mathrm{~cm}$ tall; foliage with faint pleasant odour when crushed; non-glandular and glandular trichomes uncoloured; coloured sessile glands orange, up to $c .0 .05 \mathrm{~mm}$ wide and 4-8-celled. Roots fibrous. Stem not tuberous, rounded to slightly square, fleshy, bright green when young, yellowish brown when old, transitioning to reddish-green in inflorescence, lower stem to 7-10 $\mathrm{mm}$ diameter; indumentum spreading, persistent, consisting of shorter non-glandular trichomes ( 2 or 3 cells, $0.1-0.5 \mathrm{~mm}$ long, $10-25$ trichomes/ $\mathrm{mm}^{2}$ ), longer non-glandular trichomes (up to 5-10 cells, $1.6 \mathrm{~mm}$ long, c. 3 trichomes $/ \mathrm{mm}^{2}$ or becoming more dense at nodes), glandular trichomes ( 3 cells, $0.1 \mathrm{~mm}$ long, $\left.5-33 / \mathrm{mm}^{2}\right)$, and orange-coloured sessile glands $\left(c .13 / \mathrm{mm}^{2}\right)$. Leaves light green becoming bluish green when drought stressed, discolorous; petiole $20-30 \mathrm{~mm}$ long; lamina broadly ovate (1.2-1.4 length:width ratio), 70-90 mm long, 55-70 mm wide; margin slightly recurved and crenate with (10)14-16 teeth on each side of lamina; apex acute to obtuse; base truncate; adaxial lamina surface midgreen with longer non-glandular trichomes (5-10 cells, $1-2 \mathrm{~mm}$ long, $c .1 / \mathrm{mm}^{2}$ ), shorter non-glandular trichomes ( 3 cells, $0.1-0.5 \mathrm{~mm}$ long, c. $2 / \mathrm{mm}^{2}$ ), glandular trichomes ( 2 cells, $0.05-0.1 \mathrm{~mm}$ long, $2-10 / \mathrm{mm}^{2}$ ), lacking orange-coloured sessile glands; abaxial surface with non-glandular trichomes restricted to veins (4-8 cells, $0.5-1 \mathrm{~mm}$ long, 5-20/ $\mathrm{mm}^{2}$ ), glandular trichomes ( 1 or 2 cells, $0.02-0.05 \mathrm{~mm}$ long, 3-4/. $\mathrm{mm}^{2}$ ) and orange-coloured sessile glands (1-6/ $\mathrm{mm}^{2}$ ) positioned in deeply recessed pits. Inflorescence up to $250 \mathrm{~mm}$ long, comprising 1-3 branches from near the base; subtending leaves narrow ovate (3-6 length:width ratio), 4-8 $\mathrm{mm}$ long, $2-5 \mathrm{~mm}$ wide, crenate with 5-12 teeth on each side of lamina, abaxial surface indumentum with antrorse non-glandular trichomes (5-10 cells, 0.1-0.7 $\mathrm{mm}$ long, $25-35 / \mathrm{mm}^{2}$ ), glandular trichomes ( 1 or 2 cells, c. $0.2 \mathrm{~mm}$ long, c. $16 / \mathrm{mm}^{2}$ ), and sessile glands (up to $10-15 / \mathrm{mm}^{2}$ ), adaxial surface indumentum with antrorse non-glandular trichomes (5-10 cells, $\left.0.1-0.7,9-12 / \mathrm{mm}^{2}\right)$ and glandular trichomes ( 1 or 2 cells, c. $0.2 \mathrm{~mm}$ long, 6 or $\left.7 / \mathrm{mm}^{2}\right)$; bract reddish green, early caducous and not forming a coma, ovate to broadly ovate (1-1.6 length:width ratio, $0.2-0.4$ length at maximum width:length), 1-2 $\mathrm{mm}$ long, $1-1.5 \mathrm{~mm}$ wide, abaxial non-glandular trichomes (5-10 $\mathrm{mm}$ cells, $0.2-0.6 \mathrm{~mm}$ long, $5-10 / \mathrm{mm}^{2}$ ), abaxial glandular trichomes ( 2 cells, $0.02-0.03 \mathrm{~mm}$ long, 2 or $3 / \mathrm{mm}^{2}$ ) and abaxial orange-coloured sessile glands $\left(1-2 / \mathrm{mm}^{2}\right)$; verticillaster (6-)12-14(-16)-flowered; pedicel 3-4.5 mm long, 1-1.5 mm diameter, non-glandular trichomes (2-6 cells, $0.02-0.2 \mathrm{~mm}$ long, c. $40 / \mathrm{mm}^{2}$ ), glandular trichomes (1 cell, c. $0.3 \mathrm{~mm}$ long, c. $4 / \mathrm{mm}^{2}$ ) and sessile glands (c. 1/ $\mathrm{mm}^{2}$ ). Calyx reddish or purplish green becoming maroon at lobe apices, indumentum and glands sparse towards lobes, lobes flared, c. $3 \mathrm{~mm}$ long, accrescent; tube $0.9-1.1 \mathrm{~mm}$ long, $c .1 \mathrm{~mm}$ wide, non-glandular trichomes (3-7 cells, $0.1-0.5 \mathrm{~mm}$ long, $10-40 / \mathrm{mm}^{2}$ ), glandular trichomes (1-3 cells, $<0.05 \mathrm{~mm}$ long, $15-30 / \mathrm{mm}^{2}$ ), sessile glands (10-15/ $\left.\mathrm{mm}^{2}\right)$; adaxial (upper) lobe broadly ovate (c. 1 length:width ratio), $1-2 \mathrm{~mm}$ long, $1-1.5 \mathrm{~mm}$ wide; lateral lobes $1-2 \mathrm{~mm}$ long, $0.5-1 \mathrm{~mm}$ wide; abaxial (lower) lobes $1-2 \mathrm{~mm}$ long, $0.3-0.7 \mathrm{~mm}$ wide; Fruiting calyx golden brown; pedicel 3-4.5 mm long; tube 1-1.4 mm long; adaxial lobe broadly ovate (c. 1 length:width ratio), $1.5-3 \mathrm{~mm}$ long , c. $2 \mathrm{~mm}$ wide; lateral lobes $1.5-2.5 \mathrm{~mm}$ long, $0.9 \mathrm{~mm}$ wide; abaxial lobes $2.3-2.6 \mathrm{~mm}$ long, $0.5-1 \mathrm{~mm}$ wide. Corolla 10-12 mm long, lilac-purple in bud; tube lilac-purple (or more bluish when older) fading to white near base, 4.5-5.5 mm long, 1-1.8 mm high, 1-1.3 mm wide at base, bent upwards $c .115^{\circ}$ at $c .1 .5 \mathrm{~mm}$ from base (measured from abaxial side), slightly inflated and bent downwards $105-115^{\circ}$ at $c .3 \mathrm{~mm}$ from base (measured from abaxial side), trichomes and glands absent; adaxial median lobe-pair blue, 1.5-2.5 mm long, 1-2 mm high, 1.5-2.5 mm wide, non-glandular trichomes $2-4 / \mathrm{mm}^{2}$, glandular trichomes absent, orange-coloured sessile glands 4 or $5 / \mathrm{mm}^{2}$; lateral lobes blue with white stripe, $0.3-0.7 \mathrm{~mm}$ long, $0.5-1.5 \mathrm{~mm}$ wide, reflexed $90-100^{\circ}$ away from floral tube axis, nonglandular trichomes $2-4 / \mathrm{mm}^{2}$, glandular trichomes absent, orange-coloured sessile glands 4 or $5 / \mathrm{mm}^{2}$; abaxial lobe blue 4.5-6 $\mathrm{mm}$ long, c. $1 \mathrm{~mm}$ wide, 5-6 $\mathrm{mm}$ wide (when spread out), non-glandular trichomes $2 \mathrm{or} 3 / \mathrm{mm}^{2}$, glandular trichomes absent, sessile glands 2 or $3 / \mathrm{mm}^{2}$. Stamen inserted 4-6 mm from base of corolla, reaching $0.9-1.3 \mathrm{~mm}$ short of the tip of the abaxial corolla lobe; filament blue, 3-4.5 mm long, c. $0.15 \mathrm{~mm}$ wide; anther blue, $0.5-1.5 \mathrm{~mm}$ long, 0.4-1.2 mm wide, pollen bright orange. Gynoecium pistil lilac-purple, 7-10 $\mathrm{mm}$ long, stigma lower lobe $0.4-0.5$ $\mathrm{mm}$ long, upper lobe $0.3-0.7 \mathrm{~mm}$ long; disc $0.1-0.3 \mathrm{~mm}$ long, abaxial outgrowth $0.5-0.8 \mathrm{~mm}$ long; ovule $0.3 \mathrm{~mm}$ long, $0.25 \mathrm{~mm}$ wide. Fruit a mericarp, dark brown, smooth, c. $0.7 \mathrm{~mm}$ long, c. $0.5 \mathrm{~mm}$ wide. Figs 2, 3 . 


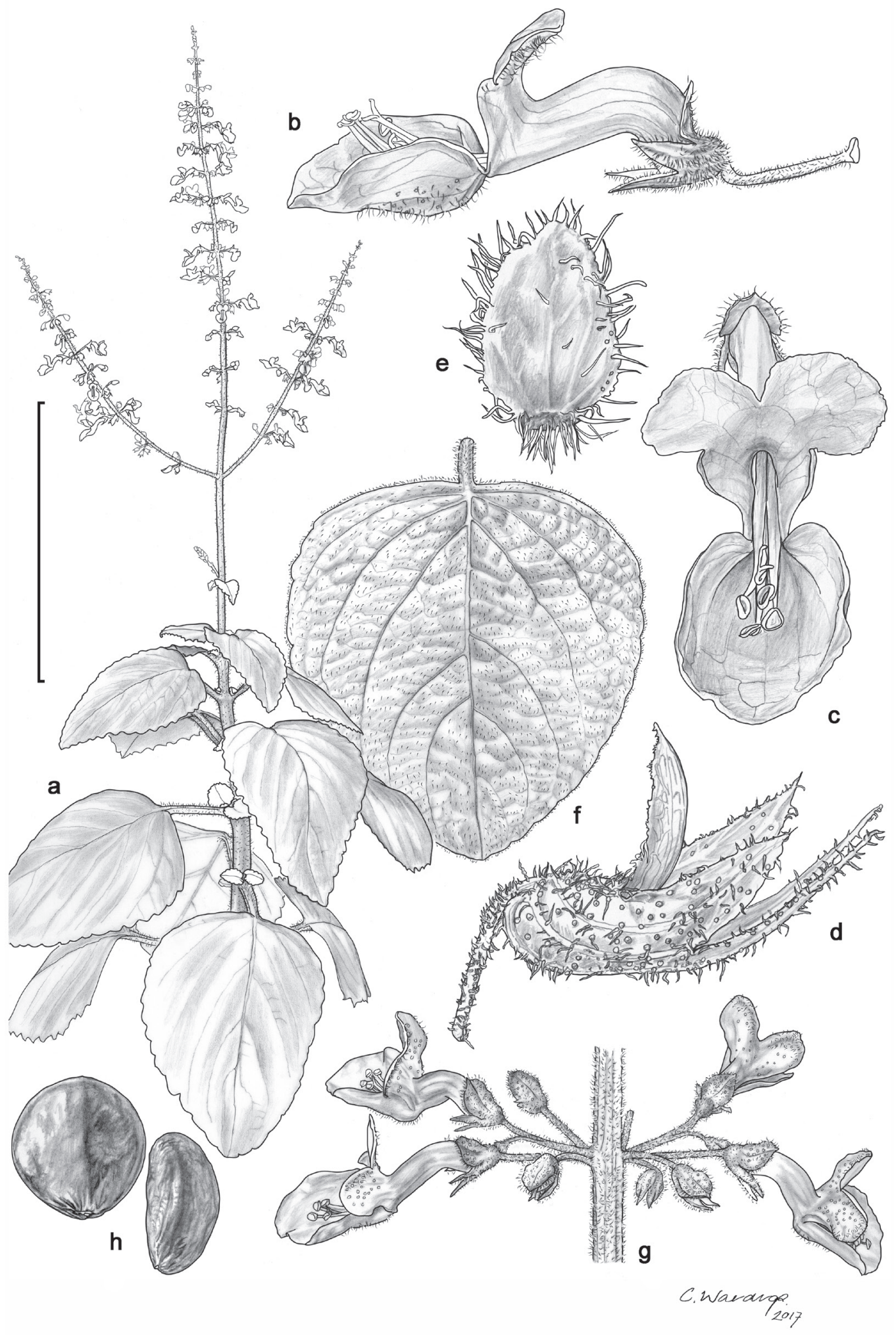

Fig. 2. Plectranthus amiculatus. A, habit; B, flower, lateral view; C, bract, abaxial view; D, flower, front view; E, leaf, adaxial view; F, calyx (fruiting), lateral view; $\mathbf{G}$, verticillaster with flowers and young buds; $\mathbf{H}$, mericarp, front (left) and lateral (right) view. Scale bar: $\mathrm{A}=12 \mathrm{~cm} ; \mathrm{B}=0.75 \mathrm{~cm} ; \mathrm{c}=0.6 \mathrm{~cm} ; \mathrm{d}=0.33 \mathrm{~cm} ; \mathrm{e}, \mathrm{h}=0.2 \mathrm{~cm} ; \mathrm{f}=6 \mathrm{~cm} ; \mathrm{g}=1.2 \mathrm{~cm}$. Illustration: C. Wardrop. 


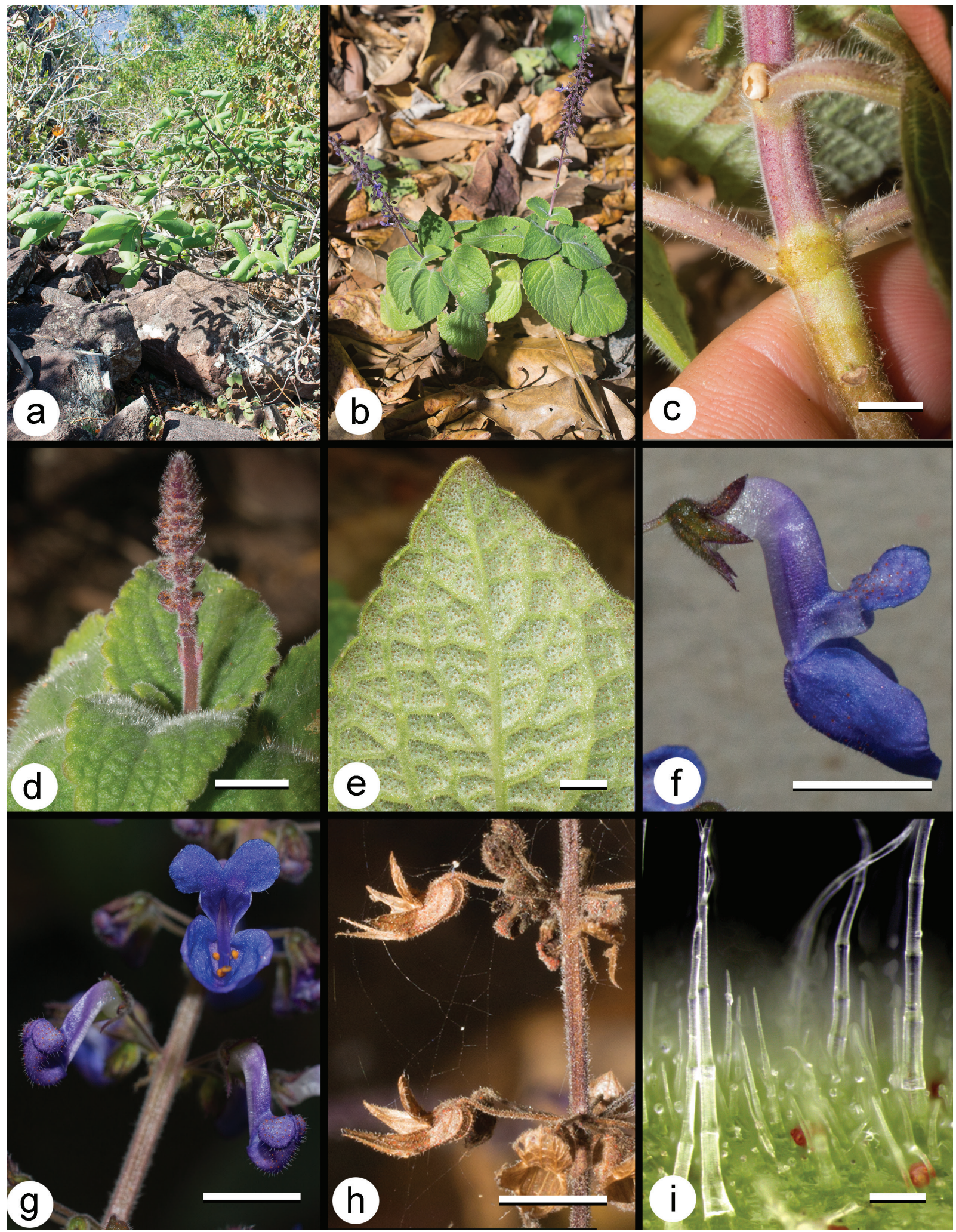

Fig. 3. Plectranthus amiculatus. A, habitat; B, habit; C, stem and petioles; D, young inflorescence with bracts and showing adaxial surface of leaves; E, leaf apex (abaxial surface); F, flower, lateral view; G, flower, front view; H, fruiting calyx, lateral view; I, non-glandular trichomes, glandular trichomes and sessile glands on stem surface. Scale bar: $\mathrm{C}-\mathrm{E}=10 \mathrm{~mm}$; $\mathrm{F}-\mathrm{H}=2.5 \mathrm{~mm} ; \mathrm{I}=0.1 \mathrm{~mm}$. Photographs: T.C. Wilson.

Other specimens examined: AUSTRALIA: QUEENSLAND: Cook District: Goode Island, $10^{\circ} 34^{\prime} 0^{\prime \prime} \mathrm{S}, 142^{\circ}$ 9'0" E. W., 1881, Powell 8, (MEL); northern base of Mt Bremer, 26.3km NE of Bamaga, 10 $41^{\prime} \mathrm{S}, 1^{\circ} 2^{\circ} 31^{\prime} \mathrm{E}$, 24 Feb 1994, D.G. Fell DGF4049 (BRI); Along Pajinka Road, 10 42.187' S, 142 31.850' E (Cultivated at Sydney Royal Botanic Gardens) 4 Nov 2017: T.C. Wilson 774, (NSW). 
Habitat: Plectranthus amiculatus grows on shallow slopes and in recesses associated with outcrops/escarpments and drainage lines; often in skeletal soils of dark humus and amongst boulders derived from sedimentary beds (sandstone), at elevations between 0 and $50 \mathrm{~m}$ (Fig. 3a). Associated vegetation consists of riparian areas and thickets of semi-deciduous dry rainforest.

Etymology: The specific epithet 'amiculatus' refers to the cloaking nature of the slightly convex leaves that hang around the stem, particularly around the shoot tip.

Distribution: Based on the outcrop habitat associated with the collections we have examined, from satellite imagery of the surrounding area of far north Queensland we estimate the distribution of P. amiculatus could extend to approximately $50 \mathrm{~km}^{2}$; this covers the area around the peninsular tip and the nearby Torres Strait islands that have similar exposed rocky outcrop habitat. The type collection of P. amiculatus is known from a population along Pajinka Road that spreads across an area of about $30 \mathrm{~m}^{2}$ and includes a total of 30 patches that can be reasonably recognised as individuals; it is unknown whether these individuals are clones. Focused searches for this species have only been conducted in the vicinity $(10 \times 10 \mathrm{~m}$ area) of this location. The Plectranthus collection from Goods (Palilug) island (Powell 8), consisting only of three inflorescence branches and a leafless stem, matches the type material of P. amiculatus better than P. apreptus since it has dark orange glands on stems and calyces, verticillasters with up to 16 flowers, and longer spreading non glandular trichomes on the calyx.

Conservation status: The distribution and population size of P. amiculatus have not been assessed extensively, we conclude that the conservation status of P. amiculatus should be regarded as data deficient as defined by the IUCN criteria (IUCN 2015).

Notes: Based on observations of cultivated material, hermaphroditic flowers of P. amiculatus are partially protandrous: anthers first become dehiscent, and while the pollen is still being presented, the style curves upwards and the stigma lobes simultaneously separate (Fig. 3g). Early anthetic flowers are a more bluish purple colour, but as anthers senesce, the flower develops a more reddish hue bordering on magenta. The pollinators of $P$. amiculatus are not known.

\section{Plectranthus altanmouiensis T.C.Wilson, P.I.Forst., \& M.A.M.Renner, sp. nov.}

Diagnosis: Plectranthus altanmouiensis T.C.Wilson, P.I.Forst., \& M.A.M.Renner, sp. nov. resembles P. diversus and P. batianoffii because it is an erect to semi-erect, non-tuberous, suffrutescent shrub with a multi-branched inflorescence and short-pedicellate flowers. Plectranthus altanmouiensis is unlike P. diversus since the stem, leaf and calyx have shorter non-glandular trichomes; 4-6-celled orange sessile glands are present on the length of the stem (as opposed to 8-celled, scattered and restricted to stem nodes); inflorescences do not produce a coma and have up to 5 branches (as opposed to coma present with 3 branches maximum); and verticillasters usually with 16 flowers (not up to 20-flowered). Plectranthus altanmouiensis is unlike P. batianoffii since nonglandular trichomes of the stem and inflorescence axis are shorter and retrorse (not antrorse), orange-coloured sessile glands of leaves and stem are 4-6-celled (not 8-celled), non-glandular trichomes of leaves shorter, nonglandular trichomes of calyx shorter and spreading (as opposed antrorse).

Type: Cape Melville National Park, Cape York, Cook District, Queensland, 14 34'20" S, 144 36'59" E, 14 Aug 2015, T.C. Wilson 610 and M.A.M. Renner (holo: NSW 985152; iso: BRI).

Erect, succulent perennial herb to $160 \mathrm{~cm}$ tall; foliage with a heady, slightly unpleasant odour when crushed; nonglandular and glandular trichomes uncoloured; coloured sessile glands orange, up to $1 \mathrm{~mm}$ wide and 4-8-celled. Roots fibrous. Stem not tuberous, erect, rounded to slightly square, fleshy, bright green when young, yellowish brown when old, transitioning to reddish-green in inflorescence, lower stem to $c .15 \mathrm{~mm}$ diameter; indumentum retrorse, persistent, consisting of non-glandular trichomes (3-5 cells, 0.2-0.5 (-0.8) mm long, 16-18 (-24) trichomes $/ \mathrm{mm}^{2}$ ), glandular trichomes ( 2 cells, $0.02-0.05 \mathrm{~mm}$ long, $2-40 / \mathrm{mm}^{2}-$ glabrescent on older stems), and orange-coloured sessile glands (4 cells, c. $0.05 \mathrm{~mm}$ long, 3-8/ $\mathrm{mm}^{2}$ ). Leaves green, discolorous; petiole (3-) $8-10 \mathrm{~mm}$ long; lamina broadly ovate (1-1.2 length:width ratio), 20-60 $\mathrm{mm}$ long, $20-55 \mathrm{~mm}$ wide; margin very slightly recurved and crenate with 15-19 (-20) teeth on each side of lamina; apex obtuse; base truncate; adaxial lamina surface green or yellowish green with non-glandular trichomes ( $2-4$ cells, $0.15-0.5 \mathrm{~mm}$ long, $8-18 / \mathrm{mm}^{2}$ ); abaxial surface pale green, veins and lamina with non-glandular trichomes (2-5 cells, $0.15-0.3 \mathrm{~mm}$ long, 25-40/ $\mathrm{mm}^{2}$ ), glandular trichomes ( 2 cells, $0.02-0.05 \mathrm{~mm}$ long, c. $10 / \mathrm{mm}^{2}$ ) and orange-coloured sessile glands (4-6 cells, $0.07-0.1 \mathrm{~mm}$ wide, $4-11 / \mathrm{mm}^{2}$ ). Inflorescence up to $250 \mathrm{~mm}$ long, comprising up to 5 pedunculate branches, subtended by a pair of reduced leaves with petiole 1-3.5 mm long, lamina 10-20 $\mathrm{mm}$ long and 7-19 $\mathrm{mm}$ wide with up to 19 teeth on each side of lamina; indumentum retrorse consisting of non-glandular trichomes (3-5 cells, $0.1-0.4 \mathrm{~mm}$ long, $\left.20-25(-35) / \mathrm{mm}^{2}\right)$, glandular trichomes (1-2 cells, $0.02-0.08 \mathrm{~mm}$ long, $\left(5-40 / \mathrm{mm}^{2}\right)$, 
and orange-coloured sessile glands (4 cells, c. $0.01 \mathrm{~mm}$ wide, (1-) 3-5/ $\mathrm{mm}^{2}$ ); bract brownish yellow to reddish green, early caducous and not forming a coma, broadly ovate (0.7-1.6 length:width ratio), (0.5-) 1-3 mm long (0.4-1.5 mm to max width), (0.5-) 1-3 mm wide, abaxial surface with non-glandular trichomes (2-5 cells, $0.1-$ $0.4 \mathrm{~mm}$ long, $25-40 / \mathrm{mm}^{2}$ ), glandular trichomes ( 1 cell, c. $0.03 \mathrm{~mm}$ long, $0-3 / \mathrm{mm}^{2}$ ) and orange-coloured sessile glands (4-8 cells, $0.05-0.08 \mathrm{~mm}$ wide, (1-) 4-8 (-10)/ $\mathrm{mm}^{2}$ ); verticillaster 12-14 (-16)-flowered; pedicel (0.5-) 1.5-2.5 mm long, 0.1-0.3 mm diameter, non-glandular trichomes (2-6 cells, $0.1-0.3 \mathrm{~mm}$ long, $10-50 / \mathrm{mm}^{2}$ ) and glandular trichomes (1-2 cells, c. $0.3 \mathrm{~mm}$ long, c. $6 / \mathrm{mm}^{2}$ ). Calyx reddish green, 2-2.5 mm long, accrescent; tube $0.8-1.4 \mathrm{~mm}$ long, $c .1 .5 \mathrm{~mm}$ wide, with indumentum of antrorse to spreading non-glandular trichomes (3--6) cells, $0.2-0.5 \mathrm{~mm}$ long, (25-) 40-55/ $\mathrm{mm}^{2}$ ), sessile glands (4-8 cells, $0.2-0.25 \mathrm{~mm}$ wide, $7-11 / \mathrm{mm}^{2}$ ); adaxial lobe broadly ovate (c. 1 length:width ratio), $0.5-1.2 \mathrm{~mm}$ long, $1-1.2 \mathrm{~mm}$ wide; lateral lobes $0.8-1.2 \mathrm{~mm}$ long, 0.3-0.8 mm wide; abaxial lobe 0.5-1 (-1.4) $\mathrm{mm}$ long, 0.4-1.2 mm wide. Fruiting calyx golden brown; pedicel 1.5-2 mm long; tube 1-1.5 mm long; adaxial lobe broadly to transverse broadly ovate (length:width ratio $0.9-1.3$ ), 1-1.5 mm long, $0.9-1.5 \mathrm{~mm}$ wide; lateral lobes $1-2 \mathrm{~mm}$ long, $c .0 .5 \mathrm{~mm}$ wide; abaxial lobes c. $2 \mathrm{~mm}$ long, c. $0.5 \mathrm{~mm}$ wide. Corolla 8-11 mm long, lilac-purple in bud, outer surfaces covered with nonglandular trichomes (0.1-0.3 mm long and 2-5 celled); tube lilac-purple fading to white near base, 4-6 mm long, 0.9-1.2 $\mathrm{mm}$ high, 0.6-1.1 wide, bent upwards $120-130^{\circ}$ (measured from abaxial side) at $0.7-1 \mathrm{~mm}$ from base, slightly inflated and bent downwards $95-115^{\circ}$ (measured from abaxial side) at 2-2.7 $\mathrm{mm}$ from base, non-glandular trichomes $7-18 / \mathrm{mm}^{2}$; upper lip (adaxial median lobe-pair and lateral lobes) blue, $0.5-1.5 \mathrm{~mm}$ long, c. $3.5 \mathrm{~mm}$ wide, with outside surfaces covered with non-glandular trichomes $\left(10-35 / \mathrm{mm}^{2}\right)$ and orangecoloured sessile glands $\left(8-12 / \mathrm{mm}^{2}\right)$, adaxial median lobe-pair $1-2 \mathrm{~mm}$ long and c. $4 \mathrm{~mm}$ wide; lateral lobes with white midline stripe, $0.3-0.5 \mathrm{~mm}$ long, $0.5-1 \mathrm{~mm}$ wide, reflexed $105-115^{\circ}$ from floral tube axis; abaxial lobe 4-5 mm long, 1-3 mm wide, (3.5-5.5 mm wide when spread out), non-glandular trichomes $5-25 / \mathrm{mm}^{2}$, orange-coloured sessile glands $5-15 / \mathrm{mm}^{2}$. Stamen inserted $3.5-5.5 \mathrm{~mm}$ from base of corolla, exserted $-0.5-$ (-1.5) $\mathrm{mm}$ from tip of lower lobe; filament lilac-purple, 3.5-4.5 mm long, 0.2-0.25 mm wide; anther dark blue, c. 0.4-0.5 mm long, c. 0.4-0.45 mm wide, pollen bright orange. Gynoecium pistil lilac-purple, 7-10 $\mathrm{mm}$ long, lower stigma lobe $0.2-0.4 \mathrm{~mm}$ long, upper lobe $0.2-0.4 \mathrm{~mm}$ long; disc c. $0.25 \mathrm{~mm}$ long, $c .0 .5 \mathrm{~mm}$ wide, abaxial outgrowth $c .0 .5 \mathrm{~mm}$ long; ovule $c .0 .25 \mathrm{~mm}$ long, $c .0 .25 \mathrm{~mm}$ wide. Fruit a mericarp, dark brown, shiny with dark spots, c. $2 \mathrm{~mm}$ long, c. $2 \mathrm{~mm}$ wide. Figs 4, 5 .

Other specimens examined: AUSTRALIA: QUEENSLAND: CooK District: Cape York: Cape Melville National Park: Altanmoui Range Section: 14 34' 20"S, 144³6' 59"E, 24 May 1993, V.J. Neldner 3986 (BRI); $14^{\circ}$ 33'24"S, 144 38'12"E, 6 June 2011, K.R. Mcdonald KRM11424 (BRI).

Etymology: the specific epithet refers to the distribution of this species in the locality of the Altanmoui Range.

Distribution: Plectranthus altanmouiensis is known from three collections from the Altanmoui Range, Cape Melville in far-north Queensland.

Habitat: Steep slopes, crests and ridges associated with outcrops/escarpments and other exposed places at elevations between 250 and $600 \mathrm{~m}$. Substrate generally includes skeletal soils amongst boulders (Fig 5a) derived from sedimentary rock. Surrounding vegetation consists of open woodland, chiefly composed of Allocasuarina sp., Corymbia sp. and Acacia sp., or araucarian microphyll vine-forest.

Conservation status: This species is known from three collections distributed over four kilometres across the Altanmoui Range, Cape Melville National Park. Based on similar exposed conditions found across the range, a conservative estimate for the distribution of $P$. altanmouiensis would be approximately $25 \mathrm{~km}^{2}$. Focused searches have not yet been conducted to determine the extent of similar surrounding habitats outside this region. Since the distribution and population size of $P$. altanmouiensis have not been assessed extensively, we conclude that the conservation status of $P$. altanmouiensis should be regarded as data deficient as defined by the IUCN criteria (IUCN 2015).

Notes: Like many species of Plectranthus in Australia, the habit can appear very different between younger plants and reproductive or drought stricken plants. Younger plants appear leafy (fig. 5b) whereas those bearing inflorescences can lose their larger leaves (Fig. 5a,f). Based on observation of material at the type location, hermaphroditic flowers of P. altanmouiensis are incompletely protandrous: anthers dehisce first, and while the pollen is still presented, the style curves upwards and the stigma lobes separate. (Fig. 5g). The pollinators of P. altanmouiensis have not been observed. 


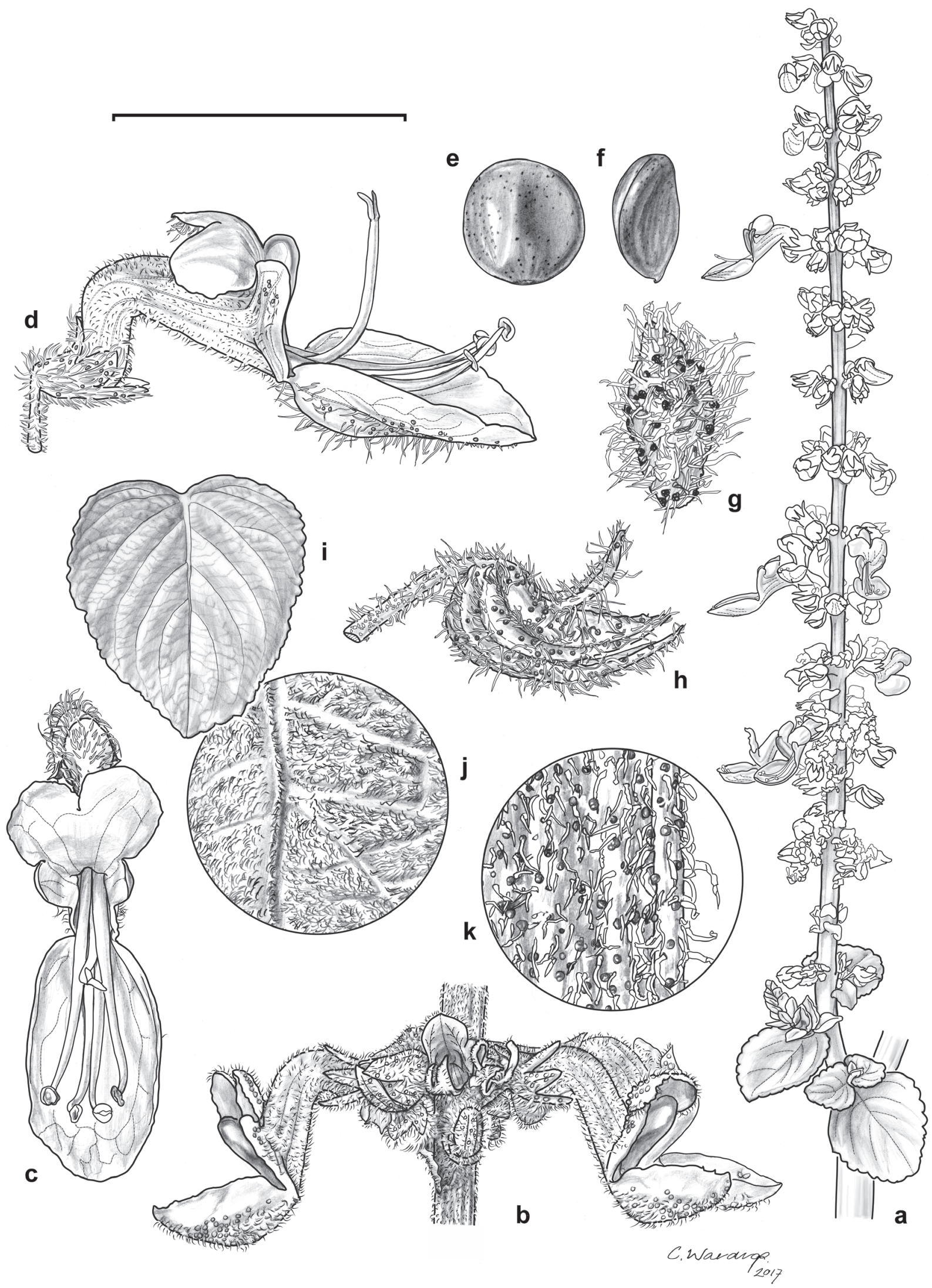

Fig. 4. Plectranthus altanmouiensis. A, habit including inflorescence; B, verticillaster with young buds, opening flowers, and fruiting calyces; C, flower, front view; D, flower, lateral view; E, mericarp, front view; F, mericarp, lateral view; G, bract, abaxial surface; H, calyx (fruiting), lateral view; I, leaf, adaxial view; J, leaf, magnified view of abaxial surface; $\mathbf{K}$, stem, magnified view of indumentum on surface. Scale bar: $A=2 \mathrm{~cm} ; B, j=1 \mathrm{~cm} ; C, D=0.6 \mathrm{~cm} ; E, F, G, K=0.2 \mathrm{~cm}$; $\mathrm{I}=6 \mathrm{~cm}$. Illustration: C. Wardrop. 


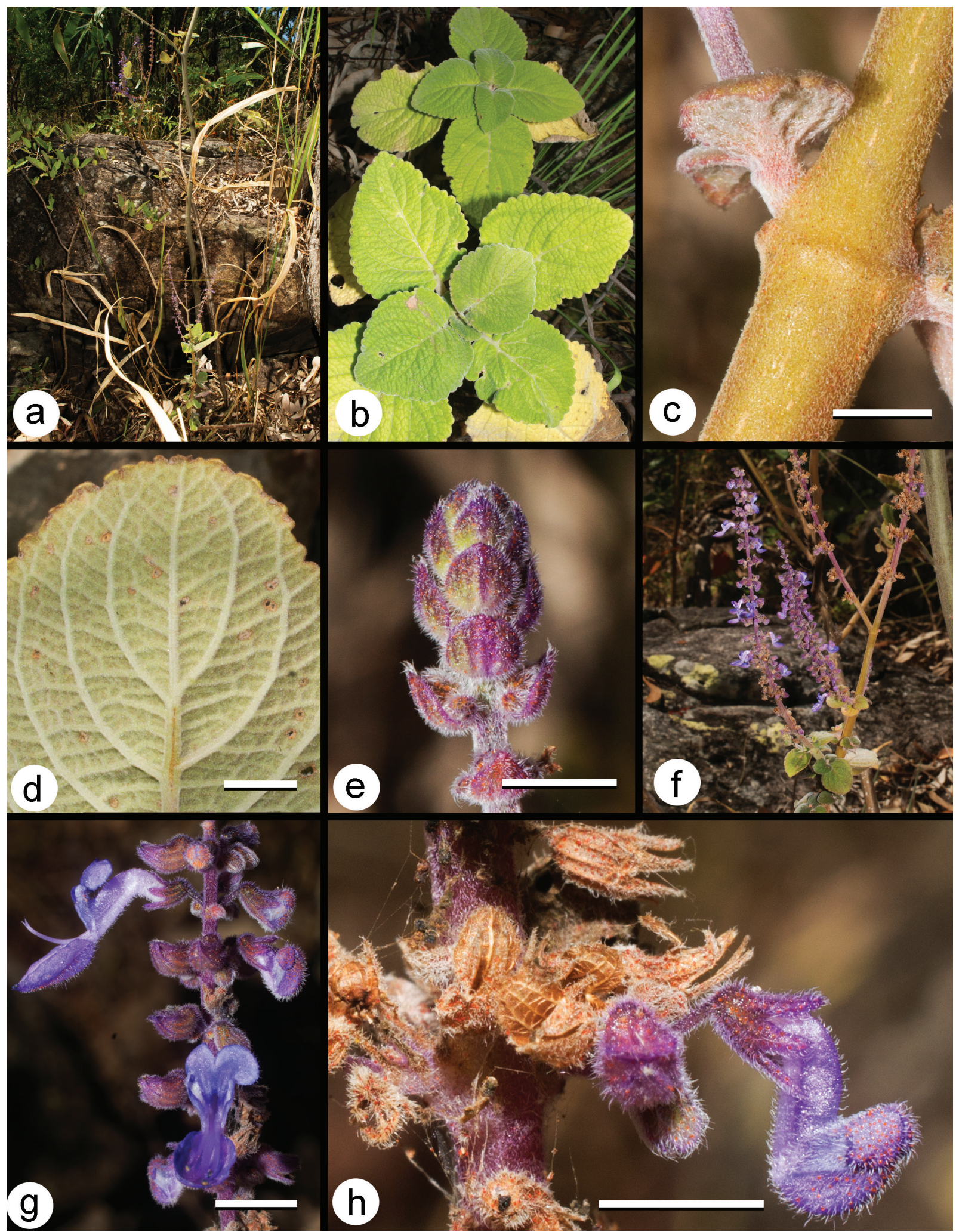

Fig. 5. Plectranthus altanmouiensis. A, habitat and habit; B, habit; C, stem showing node and internodes; D, leaf apex (abaxial surface); E, young inflorescence with bracts; F, inflorescence; G, buds and flowers; $\mathbf{H}$, verticillaster with fruiting calyces and young flower buds. Scale bar: $\mathrm{C}-\mathrm{D}=10 \mathrm{~mm}$; $-\mathrm{G}, \mathrm{H}=2.5 \mathrm{~mm}$. Photographs: T.C. Wilson. 
Table 1. Comparison of selected morphological characters useful for distinguishing Plectranthus amiculatus and P. altanmouiensis from other morphologically similar species. Abbreviations: NGT, Non-glandular trichomes; SG, Sessile glands.

\begin{tabular}{|c|c|c|c|c|c|}
\hline $\begin{array}{l}\text { Morphological } \\
\text { Characters }\end{array}$ & P. altanmouiensis & P. diversus & P. batianoffii & P. amiculatus & P. apreptus \\
\hline Stem NGT direction & retrorse & retrorse & antrorse & spreading & antrorse \\
\hline Stem NGT length (mm) & $<1$ & C. 2 & $<2$ & c. 1.6 & c. 1.2 \\
\hline Stem SG & 4-celled, orange, & $\begin{array}{l}\text { Scattered at nodes } \\
\text { only, 8-celled, } \\
\text { orange }\end{array}$ & 8-celled, orange & 4-8-celled, orange & 4-8-celled, yellow \\
\hline Stem SG density $\left(\mathrm{mm}^{2}\right)$ & $3-8$ & $<1$ & $<1$ & c. 13 & $0-3$ \\
\hline $\begin{array}{l}\text { Abaxial Leaf NGT density } \\
\left(\mathrm{mm}^{2}\right)\end{array}$ & $25-40$ & c. 30 & c. 20 & $\begin{array}{l}5-20 \text { restricted to } \\
\text { veins }\end{array}$ & $0-4$ \\
\hline $\begin{array}{l}\text { Adaxial Leaf NGT density } \\
\left(\mathrm{mm}^{2}\right)\end{array}$ & $10-20$ & c. 10 & $20-30$ & c. 1 & $1-4$ \\
\hline $\begin{array}{l}\text { Abaxial Leaf NGT length } \\
(\mathrm{mm})\end{array}$ & $<0.5$ & $<3$ & $<2$ & $0.5-2$ & 0.4 \\
\hline Leaf abaxial SG & 4-6-celled, orange & 8- celled, orange & 8-celled, orange & 4-8-celled, orange & $\begin{array}{l}\text { 4-8-celled, } \\
\text { yellowish orange } \\
\text { to yellow }\end{array}$ \\
\hline Inflorescence coma & absent & present & absent & absent & absent \\
\hline Inflorescence branches & $1-5$ & $1-3$ & $1-3$ & $1-3$ & $1-3$ \\
\hline Calyx NGT direction & $\begin{array}{l}\text { antrorse to } \\
\text { spreading }\end{array}$ & $\begin{array}{l}\text { antrorse to } \\
\text { spreading }\end{array}$ & antrorse & spreading & antrorse, \\
\hline Calyx NGT length (mm) & 0.5 & 1.2 & 1.2 & $0.1-0.5$ & c. 0.2 \\
\hline Verticillaster flower \# & $12-16$ & To 20 & $12-18$ & (6)12-14(16) & $6-10(16)$ \\
\hline Scent & $\begin{array}{l}\text { strong when } \\
\text { crushed }\end{array}$ & $\begin{array}{l}\text { strong scent when } \\
\text { crushed }\end{array}$ & $\begin{array}{l}\text { strong when } \\
\text { crushed }\end{array}$ & mild when crushed & no scent \\
\hline
\end{tabular}

\section{Acknowledgments}

We thank Regan Hart (Cape Melville, Flinders \& Howick Islands Aboriginal Corporation) and the traditional owners (Daarba, Junjuu, Muli, Bagaarrmugu, Wurri, Manyamarr, Gambiilmugu and Yiirrku clans) of the Cape Melville region for their assistance with logistics and guidance on their land. This paper was enhanced by the excellent botanical illustrations prepared by Catherine Wardrop (NSW). We thank Anne Hoggett (Australian Museum Lizard Island Research Station) and Neville Walsh (Royal Botanic Gardens Victoria) for their assistance with providing specimens. The helpful comments by Russell Barrett and two anonymous reviewers assisted with improving the quality of the manuscript. Trevor Wilson is supported by the Australian Biological Resources Study (ABRS) grant (RFL215-46).

\section{References}

Atlas of Living Australia (2018) Atlas of Living Australia website at http://www.ala.org.au. Accessed 12 January 2018.

Biggs, AJW, Philip, SR (1995) 'Soils of Cape York Peninsula.' (Department of Primary Industries:

Conn, BJ (1992) New species of Plectranthus and Westringia (Labiatae) from New South Wales. Telopea 4: 643-648. https://doi.org/10.7751/telopea19814950

Forster, PI (1991) Plectranthus arenicolus (Lamiaceae), a new species from Cape York Peninsula, Queensland. Muelleria 7: 417-420.

Forster, PI (1992) Five new species of Plectranthus L. Herit (Lamiaceae) from Queensland. Austrobaileya 3: 729-740.

Forster, PI (1994) Ten new species of Plectranthus L'Her. (Lamiaceae) from New South Wales and Queensland. Austrobaileya 4: 175-177.

Forster, PI (1996) Plectranthus alloplectus, P. gratus, and P. spectabilis (Lamiaceae), a trio of rock-outcrop succulents from Queensland, Australia. Haseltonia 5: 47-56.

Forster, PI (1997) Plectranthus amoenus and P. thalassoscopicus (Lamiaceae), new species for north-eastern Queensland, Australia. Austrobaileya 7: 375-378. 
Forster,PI (1998) Plectranthus fasciculatus (Lamiaceae), a new species from north-eastern Queensland, Australia. Haseltonia 6: 14-16.

Forster, PI (2008) Plectranthus batianoffii P.I.Forst. (Lamiaceae), a new species from northeast Queensland. Austrobaileya 7: 707-710.

Forster, PI (2011) Five new species of Plectranthus L.Her. (Lamiaceae) from New South Wales and Queensland. Austrobaileya 8: 392-394.

Forster, PI (2014) Diversity on a tropical sky island: two new species of Plectranthus L.Hér. (Lamiaceae) from the Hann Tableland, north-east Queensland. Austrobaileya 9: 208-215.

Forster, PI (2015) Plectranthus laetus P.I.Forst. and P. ventosus P.IForst. (Lamiaceae), new species from Cape York Peninsula, Queensland. Austrobaileya 9: 431-438.

van Jaarsveld, E (2006) 'Plectranthus: And the Art of Turning Shade to Glade.' (Fernwood Press)

Von Gnielinsky, F, Denaro, TJ, Wellman, P, Pain, CF (1997) Torres Strait Region. In 'North Queensland Geology' (Eds JHC Bain, JJ Draper.) Vol. 240/9 pp. 159-164. (Australian Geological Survey Organisation Bulletin/Queensland Department of Mines and Energy Qld Geo)

Willmott, WF, Whitaker, WG, Palfreyman, WD, Trail, DS (1973) 'Igneous and metamorphic rocks of Cape York Peninsula and Torres Strait, vol 135.' (Australian Government Publishing Service: Canberra)

Wilson, TC, Conn, BJ (2015) Two new species of Prostanthera (Lamiaceae) from south eastern Queensland. Telopea 18: 255-263. https://doi.org/10.7751/telopea8882

Manuscript received 8 November 2017, accepted 19 February 2018 
